\title{
BAHAN AJAR TEMATIK BERBASIS KOMPETENSI PESERTA DIDIK DI ABAD 21
}

\section{COMPETENCY BASED OF THEMATIC EDUCATION MATERIALS FOR STUDENTS IN $21^{S T}$ CENTURY}

\author{
Afifah Hasna Prilia*1, Sony Irianto ${ }^{2}$, Sriyanto ${ }^{3}$ \\ ${ }^{1,2,3}$ Program Studi Pendidikan Guru Sekolah Dasar, Fakultas Keguruan dan Ilmu Pendidikan, \\ Universitas Muhammadiyah Purwokerto, Indonesia \\ e-mail:*1prilia689@gmail.com, ${ }^{2}$ sonyirianto75@gmail.com, ${ }^{3}$ sriyanto1907@gmail.com
}

\begin{abstract}
ABSTRAK
Perkembangan abad 21 menuntut peserta didik untuk lebih aktif dalam berpikir dan memecahkan masalah. Oleh sebab itu, pelaksanaan pembelajaran perlu didukung adanya bahan ajar tematik yang dapat menumbuhkan kompetensi peserta didik di abad 21. Penelitian ini merupakan jenis penelitian pengembangan yang bertujuan untuk mengembangkan bahan ajar tematik berbasis kompetensi peserta didik abad 21 di Kelas V. Penelitian dan pengembangan ini mengacu pada langkah-langkah penelitian dan pengembangan dengan model 4D. Pengumpulan data pada penelitian ini yaitu menggunakan wawancara, analisis dokumen, dan angket yang disebarkan kepada ahli materi, bahasa, dan pembelajaran serta angket respon guru. Hasil penelitian dan pengembangan ini berupa bahan ajar tematik berbasis kompetensi peserta didik abad 21 di kelas $V$ sekolah dasar yang berisi enam tahap kegiatan pembelajaran. Keenam tahapan tersebut yaitu yaitu:1) memprediksikan, 2) berdiskusi I, 3) menjelaskan I, 4) pengamatan, 5) berdiskusi II, 6) menjelaskan II. Bahan ajar tematik pada tahap pertama dinyatakan layak oleh ketiga validator dengan kategori "baik”. Pada tahap kedua bahan ajar tematik dinyatakan layak dengan kategori "sangat baik". Menurut respon guru dengan kategori "sangat baik". Dengan demikian bahan ajar tematik tersebut dinyatakan layak digunakan untuk meningkatkan kemampuan empat kompetensi peserta didik abad 21di sekolah dasar.
\end{abstract}

Kata kunci: Bahan ajar, Tematik, Empat Kompetensi Peserta Dididk Abad 21

\begin{abstract}
Undergoing development in $21^{\text {st }}$ century demands students to be more active in thinking and solving problems, thus education implementation needs support from thematic education materials that can grow students' competency in $21^{\text {st }}$ century. This is a research and development study aiming to develop competency based of thematic education materials on students in $21^{\text {st }}$ century of grade $V$. this research refers to $4 D$ model of research steps. Data collection using interview, document analysis, and questionnaires distributed to the experts of language and education, and teachers' responses were used. The result of this study obtains six education steps for students in $21^{\text {st }}$ century as follows: 1) prediction; 2) discussion I; 3) explanation I; 4) observation; 5) discussion II; and 6) explanation II). First step of thematic education material is feasible by obtaining 3 validations with "good" category. Second step of thematic education material obtain "very good" category. And teachers' responses obtain "very good" category. We conclude that thematic education material is feasible to be implemented to improve four competencies of students of elementary school in $21^{\text {st }}$ century.
\end{abstract}

Keywords: education material, thematic, four competencies of students in $21^{\text {st }}$ century 


\section{PENDAHULUAN}

Pembelajaran tematik merupakan bagian dari pembelajaran terpadu yang memadukan beberapa muatan pembelajaran dalam satu tema. Adanya tema memmbuat pembelajaran menjadi lebih konkret bagi peserta didik [1]. Pembelajaran tematik dapat lebih optimal jika didukung dengan bahan ajar yang disusun sendiri oleh guru. Hal ini karena guru lebih memahami kondisi peserta didik di lapangan, sehingga isi dari bahan ajar tersebut dapat disesuaikan.

Pembelajaran tematik dalam kurikulum 2013, perlu merujuk pada peraturan yang berlaku agar pelaksanaannya tidak melenceng. Oleh sebab itu, dengan merujuk pada peraturan yang berlaku, bahwa pembelajaran peserta didik di jenjang dasar dan menengah perlu memunculkan penguatan kompetensi abad 21 yang meliputi berpikir kritis, komunikasi, kreativitas, dan berkolaborasi [2]. Pertama, kompetensi berpikir kritis yakni kemampuan seseorang untuk menilai sesuatu secara orisinal dan dapat mengambil keputusan secara akurat. Indikator berpikir kritis yaitu seseorang dapat mengenal masalah, mengumpulkan banyak informasi, menentukan solusi dengan tepat, menilai fakta, menghubungkan dan memberikan kesimpulan [3]. Berpikir kritis akan menjadikan peserta didik lebih mandiri, berdisiplin diri, memonitor diri, serta dapat memperbaiki proses berpikir [4].

Kedua, kompetensi komunikasi sangat penting bagi peserta didik untuk berinteraksi dengan baik. Komunikasi merupakan kemampuan peserta didik untuk menyampaikan suatu ide atau gagasan baik secara lisan maupun secara tulisan. Indikator komunikasi yakni mampu dengan baik mengutarakan ide saat berdiskusi di dalam dan di luar kelas, memiliki sikap untuk mampu mendengarkan dan menghargai pendapat orang lain, komunikasi tidak terbatas dengan multibahasa [3]. Ketiga, kompetensi kreativitas yakni kemampuan menumbuhkan ide dan gagasan baru. Kreatif berhubungan dengan menemukan dan menghasilkan sesuatu yang baru. Indikator kreativitas dapat dinilai dari banyaknya ide yang dimiliki, kemampuan yang tinggi dalam mengembangkan, melaksanakan, dan menyampaikan gagasan baru secara lisan dan tulisan, mampu mengemukakan ide kreatif, kemampuan untuk menciptakan sesuatu yang baru berdasarkan pada pengetahuan awal yang dimiliki, dan mampu beradaptasi dalam situasi baru [3].

Keempat, kompetensi berkolaborasi penting dimiliki peserta didik agar mampu bekerja sama dalam kelompok. Indikator kompetensi berkolaborasi yakni mampu beradaptasi dalam suatu kondisi, bertanggung jawab atas tugas yang dimiliki. Memiliki rasa empati dan menghormati pendapat orang lain, serta mampu berkompromi dengan peserta didik yang lain dalam kelompok demi tercapainya tujuan [3]. Indikator dari kecakapan berkolaborasi yakni bertanggungjawab untuk menghasilkan tujuan tertentu; menghargai dan menghormati pendapat orang lain; dapat bekerja sama dalam satu tim [5].

Empat kompetensi tersebut harus dimiliki oleh peserta didik untuk mengikuti perkembangan pembelajaran abad 21. Peserta didik akan dituntut untuk lebih aktif dalam berpikir dan memecahkan masalah, sehingga terbentuk kepribadian yang kreatif, inovatif, dan mandiri dalam dirinya. Oleh sebab itu, guru juga dituntut mampu mempunyai kreativitas yang tinggi untuk menyusun dan mengembangkan bahan ajar yang sesuai dengan kebutuhan peserta didik. Menyusun bahan ajar juga merupakan salah satu tugas professional yang semestinya dimiliki oleh guru [6]. Bahan ajar yang efektif dapat menunjang proses pembelajaran serta tercapainya tujuan yang telah ditetapkan.

Perkembangan abad 21 menuntut peserta didik untuk lebih aktif dalam berpikir dan memecahkan masalah. Kemampuan berpikir dan memecahkan masalah sangat diperlukan peserta didik, agar dalam hidup bermasyarakat peserta dapat menyelesaikan permasalahan dengan baik. Sementara itu, hasil observasi menunjukkan, peserta didik masih kurang kemampuannya dalam menyelesaikan masalah. Masalah yang dimaksud adalah masalah-masalah yang berkaitan dengan muatan pelajaran, khususnya soal-soal yang membutuhkan pemikiran tingkat tinggi. Oleh sebab itu, diperlukan perangkat pembelajaran yang dapat mendukung peserta didik untuk dapat memecahkan masalah.

Bahan ajar merupakan salah satu perangkat pembelajaran yang diperlukan dalam kegiatan belajar mengajar. Berdasarkan pengamatan awal ditemukan beberapa masalah terkait 
buku ajar yang digunakan. Buku ajar yang digunakan di SDN Ledug adalah buku guru dan buku siswa, serta pendamping belajar yang terdiri dari Bupena dan Lembar Kerja Siswa (LKS). Diketahui dari hasil wawancara buku ajar dan buku pendamping belum sepenuhnya berisi empat kompetensi peserta didik abad 21. Materi yang disajikan dalam bahan ajar juga masih materi dasar dan terbatas. Oleh sebab itu, perlu adanya perbaikan pada buku siswa Tema 8 Lingkungan Sahabat Kita Subtema 3 Usaha Pelestarian Lingkungan Hidup Pembelajaran 1.

Kompetensi empat peserta didik abad 21 dapat ditunjang dengan buku siswa yang terintegrasi dengan strategi pembelajaran, meliputi predict, discuss I, explain I, observe, discuss II, explain II (PDEODE) [7]. Strategi ini memberikan kesempatan kepada peserta didik untuk menggali pengetahuan awal, mendukung adanya kerjasama antar peserta didik, serta mendorong peserta didik berbendapat dan memotivasi peserta didik [8]. Peserta didik dapat membangun pengetahuan dan pada akhirnya mengembangkan konsep baru [9]. Kompetensi peserta didik abad 21, juga sesuai dengan karakteristik pembelajaran tematik [10]. Dengan demikian, melalui buku ajar berbasis kompetensi abad 21 dapat membuat peserta didik menjadi produktif dan kreatif, serta mendukung pembelajaran yang inovatif dan efektif.

\section{METODE PENELITIAN}

Jenis penelitian ini yaitu Research and Development (R\&D) dengan menggunakan model pengembangan 4D. Langkah-langkah dalam 4D meliputi pendefisnisian, perancangan, pengembangan, penyebaran. Mengingat keterbatasan waktu, penelitian ini hanya dilaksanakan sampai tahap pengembangan. Produk dari penelitian ini adalah bahan ajar tematik dalam bentuk buku teks berbasis empat keterampilan abad 21 .

Penelitian dilaksanakan pada semester II tahun ajaran 2019/2020, di kelas V SD Negeri Ledug, Kabupaten Banyumas. Teknik pengumpulan data yang digunakan dalam penelitian ini yakni wawancara atau interview, analisis dokumen, dan penilaian produk oleh ahli menggunakan slaka likert. Validasi produk dilakukan oleh satu orang ahli materi, satu orang ahli bahasa, dan satu orang ahli pembelajaran serta saran dari guru yang diperoleh dari angket respon guru kelas $\mathrm{V}$ di SD Negeri Ledug, Kabupaten Banyumas. Adapun instrumen pengumpulan data yang digunakan adalah: (1) pedoman wawancara, (2) pedoman analisis dokumen, (3) skala penilaian produk.

Teknik analisis data yang dilakukan meliputi analisis data sebelum pelaksanaan penelitian, data proses pengembangan produk, dan data setelah pengembangan produk. Data sebelum pelaksanaan penelitian dalam bentuk wawancara prasurvei dengan teknik deskriptif. Data proses pengembangan produk digunakan untuk kegiatan uji kelayakan produk dengan menggunakan skala likert dan dianalisis menggunakan konversi data kuantitatif ke data kualitatif. Data setelah pengembangan produk digunakan untuk mengetahui efektivitas produk yang dikembangkan.

\section{HASIL DAN PEMBAHASAN}

\section{Hasil Penelitian}

Penelitian dan pengembangan produk terbagi menjadi tiga tahapan yaitu menganalisis dan pengumpulan data yang relevan, perencanaan, dan pengembangan draf awal produk. Masingmasing tahapan menghasilkan data untuk penyusunan produk penelitian dan pengembangan bahan ajar tematik. Adapun hasil lengkap dari setiap tahap adalah sebagai berikut: pada tahap menganalisis dan pengumpulan data yakni mencari informasi yang relevan tentang perlunya pengembangan bahan ajar tematik berupa buku teks pelajaran berbasis empat keterampilan peserta didik abad 21 yakni berpikir kritis, komunikasi, kreativitas, dan berkolaborasi. Kegiatan diawali dengan melakukan wawancara kepada guru dan kepala sekolah. Oleh sebab itu, untuk memperkuat hasil wawancara, dilakukan analisis dokumen yang berupa telaah buku teks 
pelajaran seperti buku guru dan buku siswa dari Kementrian Pendidikan dan Kebudayaan Indonesia, Bupena dan LKS serta menelaah Rencana Pelaksanaan Pembelajaran (RPP) yang disusun oleh guru kelas V. Dari hasil wawancara disimpulkan bahwa dibutuhkan pengembangan bahan ajar tematik berupa buku teks pelajaran berbasis empat keterampilan peserta didik abad 21 yang dapat meningkatkan kemampuan berpikir kritis, komunikasi, kreativitas, dan berkolaborasi pada peserta didik.

Dari hasil penelitian dan pengumpulan data melalui analisis kebutuhan dengan cara wawancara, analisis dokumen, penyebaran angket guru, maka dapat diambil kesimpulan bahwa guru dan peserta didik membutuhkan bahan ajar tematik berupa buku teks pelajaran untuk meningkatkan kemampuan keterampilan abad 21 (berpikir kritis, komunikasi, kreativitas, dan berkolaborasi) pada peserta didik kelas V SD Negeri Ledug. Bahan ajar tematik berupa buku teks pelajaran berbasis empat keterampiloan peserta didik abad 21. Pada SD Negeri Ledug belum terdapat bahan ajar tematik berbasis empat keterampilan peserta didik abad 21 untuk kelas V.

Pada tahap kedua yakni perencanaan, dirumuskan rencana pengembangan berdasarkan hasil dari analisis kebutuhan dengan dilakukannya studi pustaka yakni melakukan kajian teori yang berkaitan dengan empat komptensi peserta didik abad 21 seperti berpikir kritis, komunikasi, kreativitas, dan berkolaborasi. Kegiatan studi pustaka juga dilengkapi dengan mengkaji materi dalam buku guru dan buku siswa kelas V SD Negeri Ledug Kurikulum 2013. pada Tema 8 "Lingkungan Sahabat Kita" Subtema 3 "Usaha Pelestarian Lingkungan Hidup" Pembelajaran 1. Tahap ketiga yakni menyusun produk awal.

Produk awal penelitian berupa rancangan bahan ajar yang disusun dalam bentuk buku dengan ukuran A4. Format tulisan disesuaikan dengan kebutuhan peserta didik. Produk juga dilengkapi dengan gambar-gambar yang mendukung. Materi pelajaran dalam bahan ajar dipilih sesuai dengan tema, KD dan indikator pembelajaran. Kompetensi Dasar (KD) yang ditentukan yakni Tema 8 "Lingkungan Sahabat Kita" Subtema 3 "Usaha Pelestarian Lingkungan Hidup" Pembelajaran 1. Mata pelajaran yang memuat adalah bahasa Indonesia KD 3.8 dan KD 4.8 dan mata pelajaran Ilmu Pengetahuan Alam (IPA) KD 3.8 dan KD 4.8.

Isi materi diambil dari berbagai sumber yakni dari buku siswa, internet, serta dari hasil pengembangan. Terdapat enam tahapan kegiatan pembelajaran dengan menggunakan strategi pembelajaran PDEODE yakni: 1) memprediksikan memuat kompetensi berpikir kritis, 2) berdiskusi I memuat tiga kompetensi yakni kompetensi berkolaborasi, kompetensi berpikir kritis, dan kompetensi kreativitas, 3) menjelaskan I memuat kompetensi komunikasi, 4) pengamatan memuat kompetensi berkolaborasi, 5) berdiskusi II memuat kompetensi berpikir kritis dan kolaborasi, dan 6) menjelaskan II memuat kompetensi komunikasi. Sebelum produk diujicobakan, produk terlebih dahulu dinilai atau validasi oleh ahli materi, ahli bahasa, dan ahli pembelajaran. Penilaian ini dilakukan untuk mengetahui kelayakan bahan ajar tematik berupa buku teks pelajaran yang dikembangkan. Buku teks pelajaran dapat diujicobakan jika dinyatakan layak oleh ahli materi, ahli bahasa, dan ahli pembelajaran. Hasil lengkap validasi tahap pertama oleh ketiga validator adalah sebagai berikut

Tabel 1. Konversi Data Kuantitatif ke Data Kualitatif

\begin{tabular}{lccc}
\hline \multicolumn{1}{c}{ Aspek } & $\begin{array}{c}\text { Jumlah } \\
\text { Skor }\end{array}$ & $\begin{array}{c}\text { Rata-rata } \\
\text { Skor }\end{array}$ & Kategori \\
\hline Kelayakan Isi & 160 & 3,6 & Valid \\
Kelayakan Bahasa & 147 & 3,3 & Valid \\
Kelayakan Sajian & 53 & 3,5 & Valid \\
Kelayakan Grafis & 130 & 3,6 & Valid \\
Rata-rata total skor & - & 3,5 & Valid \\
\hline
\end{tabular}

Berdasarkan Tabel 1 dapat dijelaskan bahwa penilaian produk bahan ajar tematik berupa buku teks berbasis empat keterampilan peserta didik abad 21 oleh ahli materi, ahli bahasa, dan ahli pembelajaran mendapat rata-rata total skor 3,5 dengan kategori valid, sehingga produk yang 
Jurnal Ilmiah KONTEKSTUAL, Volume.2, No.02, Februari 2021, pp. 69-76

dikembangkan dapat dikatakan layak. Adapun rata-rata skor untuk masing-masing aspek yaitu: aspek kelayakan isi mendapat skor 3,6 dengan kategori valid, aspek kelayakan bahasa mendapat skor 3,3 dengan kategori valid, aspek kelayakan sajian mendapatkan skor 3,5 dengan kategori valid, dan aspek grafis mendapat skor akhir 3,6 dengan kategori valid. Hasil lengkap validasi tahap kedua oleh ketiga validator adalah sebagai berikut.

Tabel 2. Konversi Data Kuantitatif ke Data Kualitatif

\begin{tabular}{lccc}
\hline \multicolumn{1}{c}{ Aspek } & $\begin{array}{c}\text { Jumlah } \\
\text { Skor }\end{array}$ & $\begin{array}{c}\text { Rata-rata } \\
\text { Skor }\end{array}$ & Kategori \\
\hline Kelayakan Isi & 190 & 4,4 & Sangat Valid \\
Kelayakan Bahasa & 178 & 4,2 & Sangat Valid \\
Kelayakan Sajian & 64 & 4,2 & Sangat Valid \\
Kelayakan Grafis & 167 & 4,7 & Sangat Valid \\
Rata-rata total skor & - & 4,4 & Sangat Valid \\
\hline
\end{tabular}

Berdasarkan Tabel 2 dapat dijelaskan bahwa penilaian produk bahan ajar tematik berupa buku teks berbasis empat keterampilan peserta didik abad 21 oleh ahli materi, ahli bahasa, dan ahli pembelajaran mendapat rata-rata total skor 4,4 dengan kategori sangat valid, sehingga produk yang dikembangkan dapat dikatakan layak. Adapun rata-rata skor untuk masing-masing aspek yaitu: aspek kelayakan isi mendapat skor 4,4 dengan kategori sangat valid, aspek kelayakan bahasa mendapat skor 4,2 dengan kategori sangat valid, aspek kelayakan sajian mendapatkan skor 4,2 dengan kategori sangat valid, dan aspek grafis mendapat skor 4,7 dengan kategori sangat valid.

Penyebaran angket kepada guru dilakukan untuk mengetahui respon terhadap bahan ajar tematik tersebut. Berdasarkan hasil angket respon guru dapat disimpulkan bahwa bahan ajar tematik berbasis empat komptensi peserta didik abad 21 layak dan baik. Hasil yang diperoleh menunjukkan bahwa skor total 64 dengan rata-rata skor total 4,3 dengan kategori sangat valid, dengan demikian bahan ajar tematik berbasis empat kompetensi peserta didik abad 21 tepat guna.

\section{Pembahasan}

Produk akhir dari pengembagan ini adalah bahan ajar tematik berupa buku teks pelajaran dengan judul "CLEVER: Buku Tematik Terpadu Kurikulum 2013, Tema 8 Lingkungan Sahabat Kita Subtema 3 Usaha Pelestarian Lingkungan Hidup Pembelajaran 1". Buku teks pelajaran ini merupakan pelengkap bahan ajar tematik Kurikulum 2013, karena buku yang dikembangkan melengkapi proses pembelajaran tematik yang tidak terdapat pada buku yang diterbitkan oleh Kementrian Pendidikan dan Kebudayan Indonesia. Terdapat enam tahapan kegiatan pembelajaran.

Buku teks pelajaran membaca yang dikembangkan ini memiliki beberapa keunggulan yaitu dapat mempermudah guru dan peserta didik dalam meningkatkan kemampuan berpikir kristis, komunikasi, kreativitas, dan berkolaborasi dengan dibuktikan dari hasil respon angket guru. Bahan ajar yang terintegritas empat kompetensi peserta didik abad 21 (4C) dapat membuat peserta didik belajar lebih mandiri [11]. Bahan ajar juga dapat memfasilitasi dan mengakomodasi peserta didik untuk belajar tanpa bergantung pada guru [12]. Bahan ajar yang terintegritas empat kompetensi peserta didik abad 21 (4C) dapat meningkatkan aktivitas belajar ditunjukan dengan mengeluarkan pendapat secara bebas dan bereksplorasi dalam menemukan suatu konsep baru serta memberikan kesimpulan secara langsung [13]. Disamping itu, penyusunan bahan ajar secara mandiri oleh guru juga menjadi alternatif dalam mengaplikasikan materi yang sesuai dengan peserta didik [14].

Bahan ajar tematik berbasis empat keterampilan peserta didik abad 21 yang dikembangkan dalam penelitian ini mempunyai kualitas yang sangat baik karena dilakukan dua kali tahap penilaian oleh para ahli. Terlihat dari segi materi yang sangat baik, segi kualitas bahasa yang sangat baik, segi sajian yang sangat baik, dan segi kualitas grafis yang sangat baik. Hal ini 
terjadi karena bahan ajar tematik berbasis empat keterampilan peserta didik abad 21 disusun secara sistematis sesuai standar penulisan baku buku teks pelajaran yaitu memenuhi unsur kelayakan materi, kelayakan bahasa, kelayakan sajian, dan kelayakan grafis [15]. Terpenuhinya kelayakan materi, bahasa, sajian, dan grafis akan membuat bahan ajar yang disajikan menjadi lebih efektif dalam mengembangkan kompetensi peserta didik [16].

Spesifikasi bentuk produk yakni: 1) Buku teks berbentuk media cetak berwarna dilengkapi dengan CD belajar ukuran buku 29,7 cm x $21 \mathrm{~cm}$; 2) Ukuran kertas yang digunakan adalah HVS 80 gr dengan ukuran A4; Tipe huruf yang digunakan adalah Baar Metanoia dengan ukuran 12 pt sesuai dengan huruf pada buku guru dan buku siswa dari Kementrian Pendidikan dan Kebudayaan Indonesia. Penyajian materi buku yang menarik dirasa mampu meningkatkan daya belajar peserta didik [17]. Disamping menarik, materi dalam buku ajar juga harus disesuaikan dengan kompetensi yang diharapkan berkembang, sehingga mempermudah proses penilian, khususnya dalam implementasi kurikulum 2013 [18]. Materi yang menarik dan tepat, juga perlu memperhatikan keterbacaan produk yang dikembangkan, karena akan mempengaruhi kemampuan peserta didik dalam memahami bahan ajar [19].

Terdapat enam tahapan pembelajaran dalam bahan ajar tematik berbasis empat komptensi peserta didik abad 21 Tema 8 "Lingkungan Sahabat Kita" Subtema 3 "Usaha Pelestarian Lingkungan Hidup" Pembelajaran 1 dengan menggunakan srategi pembelajaran PDEODE, yakni: 1) memprediksikan memuat kompetensi berpikir kritis, 2) berdiskusi I memuat tiga kompetensi yakni kompetensi berkolaborasi, kompetensi berpikir kritis, dan kompetensi kreativitas, 3) menjelaskan I memuat kompetensi komunikasi, 4) pengamatan memuat kompetensi berkolaborasi, 5) berdiskusi II memuat kompetensi berpikir kritis dan kolaborasi, dan 6) menjelaskan II memuat kompetensi komunikasi. Susunan Isi dari produk yakni: (1) Daftar Isi, (2) Petunjuk Penggunaan Buku, (3) Langkah-Langkah Pembelajaran, (4) Kompetensi Dasar dan Indikator, (5) Pedalaman Materi, (6) Daftar Pustaka.

\section{SIMPULAN}

Berdasarkan hasil penelitian dan pengembangan dapat disimpulkan bahwa bahan ajar tematik berbasis empat komptensi peserta didik abad 21 Tema 8 "Lingkungan Sahabat Kita" Subtema 3 "Usaha Pelestarian Lingkungan Hidup" Pembelajaran 1 kelas V SD Negeri Ledug disusun sesuai komponen kelayakan materi, bahasa, sajian, dan grafis. Terdapat enam tahapan pembelajaran dengan menggunakan strategi PDEODE yakni: 1) memprediksikan memuat kompetensi berpikir kritis, 2) berdiskusi I memuat tiga kompetensi yakni kompetensi berkolaborasi, kompetensi berpikir kritis, dan kompetensi kreativitas, 3) menjelaskan I memuat kompetensi komunikasi, 4) pengamatan memuat kompetensi berkolaborasi, 5) berdiskusi II memuat kompetensi berpikir kritis dan kolaborasi, dan 6) menjelaskan II memuat kompetensi komunikasi.

Berdasarkan hasil analisis data, didapatkan hasil rata-rata total skor 3,5 dengan kategori valid pada tahap validasi pertama oleh ahli materi, ahli bahasa, dan ahli pembelajaran. Tahap validasi kedua mendapatkan hasil rata-rata total skor 4,4 dengan kategori sangat valid. Respon guru yang diberikan sangat baik. Hal ini dibuktikan dari hasil angket respon guru yang mendapatkan skor total 64 dengan rata-rata skor total 4,3 dengan kategori sangat valid. Berdasarkan analisis tersebut bahan ajar tematik berbasis empat kompetensi peserta didik abad 21 Tema 8 "Lingkungan Sahabat Kita" Subtema 3 "Usaha Pelestarian Lingkungan Hidup" Pembelajaran 1 layak dan tepat guna.

\section{DAFTAR PUSTAKA}

[1] L. Antari, "Penggunaan Bahan Ajar Tematik Pembagian untuk Meningkatkan Hasil Belajar di Kelas II A MI Ahliyah II Palembang," Jurnal Aksioma, vol. 4, no. 2, pp. 22-29, 2015, 
Jurnal Ilmiah KONTEKSTUAL, Volume.2, No.02, Februari 2021, pp. 69-76

https://ojs.fkip.ummetro.ac.id/index.php/matematika/article/view/307.

[2] Mendikbud, Peraturan Menteri Pendidikan Dan Kebudayaan Republik Indonesia Nomor 103 Tahun 2014 Tentang Pembelajaran Pada Pendidikan Dasar Dan Pendidikan Menengah, no. 1. Indonesia: Kemdikbud, 2014, pp. 1-24.

[3] Kemendikbud, Panduan Implementasi Kecakapan Abad 21 Kurikulum 2013 di SMA. Jakarta: Kementerian Pendidikan dan Kebudayaan, 2017.

[4] Sumarno, "Pembelajaran Kompetensi Abad 21 Menghadapi Era Society," in Seminar Nasional Pendidikan dan Pembelajaran, 2019, pp. 272-287, [Online]. Available: http://ojs.semdikjar.fkip.unpkediri.ac.id/index.php/SEMDIKJAR/article/view/28.

[5] S. Zubaidah, "Mengenal 4C: Learning And Innovation Skills untuk Menghadapi Era Revolusi Industri 4.0," 2018, [Online]. Available: https://www.researchgate.net/publication/332469989.

[6] I. M. Sadjati, Pengembangan Bahan Ajar. Jakarta: Universitas Terbuka, 2012.

[7] W. Warsono and H. Hariyanto, Pembelajaran Aktif. Bandung: Remaja Rosdakarya, 2013.

[8] T. Dipalaya, H. Susilo, and A. Duran Corebima, "Pengaruh Strategi Pembelajaran PDEODE (Predict-Discuss-Explain-Observe-Discuss-Explain) Pada Kemampuan Akademik Berbeda Terhadap Keterampilan Komunikasi Siswa," Jurnal pendidikan: Teori, Penelitian, dan Pengembangan, vol. 1, no. 9, pp. 1713-1720, 2016, [Online]. Available: http://journal.um.ac.id/index.php/jptpp/article/view/6723.

[9] A. Prastowo, Pengembangan Bahan Ajar Tematik: Tinjauan Teoritis dan Praktik. Jakarta: Kencana, 2014.

[10] J. Delors et al., Learning: The Treasure within. France: UNESCO Publishing, 1996.

[11] E. Purnomo and T. Nugraheni, "Pengembangan Modul Tari Berbasis Digital untuk Meningkatkan Kompetensi Guru Sekolah Menengah Tari," Jurnal Seni dan Budaya, vol. 3 , no. 2, pp. 119-127, 2019, [Online]. Available: https://jurnal.unimed.ac.id/2012/index.php/GDG/article/view/14157.

[12] Jamilah, I. N. Jampel, and D. P. Parmiti, "Pengembangan Modul Pembelajaran Berbasis Discovery Mata Pelajaran IPA Siswa SD No 1 Baktiseraga Kelas IV," e-journal Edutech Universitas Pendidikan Ganesha, vol. Vol: 8 No., no. 1, pp. 189-198, 2017, [Online]. Available: https://ejournal.undiksha.ac.id/index.php/JEU/article/view/20376.

[13] R. Rasmawan, "Development of Chemistry Module for Junior High School Based on Inquiry Accompanied by Performance-Based Assessment," Jurnal Pendidikan Indonesia, vol. 7, no. 2, pp. 111-119, 2018, [Online]. Available: https://ejournal.undiksha.ac.id/index.php/JPI/article/view/10617.

[14] S. Yustiana and R. F. Kusumadewi, "Pengembangan Bahan Ajar Modul Berbasis CTL Sebagai Bagian Dari Pengembangan SSP," Jurnal Ilmiah KONTEKSTUAL, vol. 1, no. 2, pp. $1-6, \quad 2020, \quad$ [Online]. Available: http://jurnal.umus.ac.id/index.php/kontekstual/article/view/155.

[15] M. Muslich, Text Book Writing. Yogyakarta: Ar-Ruzz Media, 2010.

[16] N. Yuliyanti, R. U. Nurbaeti, and N. Afifah, "Efektivitas Bahan Ajar Berbasis Saintifik Terhadap Sikap Ilmiah Mahasiswa PGSD," Jurnal Ilmiah KONTEKSTUAL, vol. 2, no. 01, pp. $\quad 1-7, \quad 2020, \quad$ [Online]. Available: http://jurnal.umus.ac.id/index.php/kontekstual/article/view/242.

[17] L. Novita, E. Sukmanasa, and M. Y. Pratama, "Indonesian Journal of Primary Education Penggunaan Media Pembelajaran Video terhadap Hasil Belajar Siswa SD," Indonesian Journal of Primary Education, vol. 3, no. 2, pp. 64-72, 2019, [Online]. Available: https://ejournal.upi.edu/index.php/IJPE/article/view/22103.

[18] S. Mardikarini and F. Hamdani, "Pelaksanaan Penilaian Pembelajaran Menggunakan Kurikulum 2013 di SD Negeri 1 Tapak," Jurnal Ilmiah KONTEKSTUAL, vol. 01, no. 1, pp. 70-76, 2019, [Online]. Available: http://jurnal.umus.ac.id/index.php/kontekstual/article/view/61.

[19] A. Mumpuni and R. U. Nurbaeti, "Doneng Antikorupsi Sebagai Bahab Literasi Bagi Peserta Didik di Sekolah Dasar," Jurnal Ilmiah Wahana Pendidikan, vol. 6, no. 4, pp. 
573-587, 2020, [Online].

https://jurnal.unibrah.ac.id/index.php/JIWP/article/view/463.

Available: 